\title{
Diplomatic Missions of the Holy See in Hungary and East-Central Europe after the Second World War
}

\section{Margit BALOGH}

\author{
Magyar Tudományos Akadémia, Bölcsészettudományi Kutatóközpont, Történettudományi Intézet \\ Research Centre for the Humanities, Hungarian Academy of Sciences, Budapest, \\ Úri u. 53, 1014 Budapest, Hungary \\ Balogh.Margit@btk.mta.hu
}

According to Canon 265 of the 1917 Code of Canon Law "it is the right of the Roman Pontiff, independent of civil power, to send into any part of the world Legates, with or without ecclesiastical jurisdiction". In 1917 it was reasonable to refer to the independence of civil power, since between 1870 and 1929 - that is in the nearly sixty years between the cessation of the Papal States (which had been formed in 756) and the conclusion of the Lateran Treaty - Rome was not granted statehood but it signed a number of treaties, i.e. with Hungary, Romania, Poland and the Kingdom of the Serbs, Croats and Slovenes. Vatican City State was established by the Lateran Treaty, signed on 11 February 1929. Everyday language incorrectly does not distinguish the Vatican and the Holy Apostolic See. The Vatican is a 'state', whilst the Holy Apostolic See is an ecclesiastical organization: the Holy Father together with his office, the supreme authority of the Church and thus a specific subject of International Law. Diplomatic relations are established by the Holy See and not by the Vatican, therefore it is accurate to speak about the diplomatic relations of the Holy See and not that of the Vatican. ${ }^{1}$

The ranks of the papal diplomats were defined by Pope Gregory XIII (1572-1585). The permanent diplomatic representative of the Holy Apostolic See is called Apostolic Delegate if he is sent to serve as a liaison with the local Church solely and thus his mission is not that of a diplomatic character in the strict sense of the word. If he is accredited to states and governments as well, his title is Nuncio in so far as he has the right to be the Doyen of the Diplomatic Corps in the country in question. The origin of the expression and office is unexplained but there are records from the $4^{\text {th }}$ Century. Nunciatures in the modern sense were established from the end of the $15^{\text {th }}$ Century. The first Papal Nuncio was sent to Venice by Pope Alexander VI in 1500. In its diplomatic relations established since 1990, those representatives that are not accorded precedence by the host country are called Nuncio by the Holy See, too. If the papal representative does not enjoy precedence within the diplomatic corps, his title is Pro-Nuncio (typically in the decades between 1965 and 1990) or Internuncio. According to diplomatic law the Nuncio and the Pro-Nuncio are rated as ambassadors and the rank of the Internuncio is envoy extraordinary and minister plenipotentiary. ${ }^{2}$

1 Miklós RÓNAY, A Szentszék és a Vatikán Városállam viszonya a közbeszédben és a jogban, Külügyi Szemle Vol. 3, 2004, 271-289.

2 Szabolcs Anzelm SZUROMI, Egyházi intézménytörténet, Budapest 2003, 191-193. 


\section{The Soviet Union and the Holy See}

In this analysis we would like to outline how the representatives of the Holy See, assigned to the East-Central European countries, could work in the new political situation after the Second World War. We try to set it in the context of the new social, political and geographical field, which this region entered as an area occupied by the Red Army; also mentioning the Soviet Church policy practice of the new alliance.

Soviet-Russia had limited experience in the relations with the Holy See, apart from the 1922 hunger relief contract. Moreover, the anti-Catholicism fostered by the Orthodoxy was inherited from tsarist Russia and it could continue to prosper, because the Soviet regime considered the universal and combative Roman Catholic Church a much worse institution than the Russian Orthodox Church, which could be administered by the police and manipulated in favour of state policy objectives. The dualism of the foreign policy of the Holy See during the Second World War also contributed to this distrust, because although the Holy See refused to declare the German attack against the Soviet Union a crusade, at the same time it did not condemn Nazism publicly and refused to recognize that freedom of conscience was guaranteed in the Soviet Union (as it was not). The Vatican regarded Germany as the only power that could resist atheist communism and prevent its appearance in Europe.

When the Red Army crossed the borders of the East-Central European states in 1944, Soviet policy had to face a new and entirely unknown social and political reality: the Catholic Church. In Czechoslovakia, Poland and Hungary the overwhelming majority, in Yugoslavia almost half of the population has belonged to this Church for centuries. Stalin counted on this situation; this is why he had expressed his opinion on the Catholic Church from a strategic and political point of view in a characteristic way before the Red Army marched into the countries of Eastern and Central-Europe. As early as in September 1943 he established a separate organization attached to the government to execute Church policy and maintain relations with the Church. ${ }^{3}$

In Stalin's dacha on the morning of 4 September 1943 - in the presence of G. M. Malenkov, Secretary of the Central Committee, L. J. Beria, People's Commissar for State Security (NKVD) and Colonel G. G. Karpov, head of Directorate II of the NKVD, responsible for intelligence (and Churches) - Stalin analysed the situation of the Russian Orthodox Church in detail. At the end of the conversation he remarked that it was high time that a special organization was established to link the Church and the government, and at the same time he decided on the name of the new office: Council for the Affairs of the Russian Orthodox Church. Stalin laid down the following points in connection with the operation of the new council: it is "not a procuratorship" (referring to the Ober-Procurator, the head of the Church affairs in the synodical period); it must not intervene directly in Church administration, canonical and dogmatic life but it has to strengthen the independence of the Church through its activity and ensure the correct relation with the Patriarch; it must not "rummage through the pocket" of the Church, on the contrary: it has to guarantee that the Church is

3 Mikhail V. SKAROVSKI, Russkaia Pravoslavnija Cerkov pri Staline i Khrushceve (gosudarstvennoje-cerkovnie otnoseniya v SSSR v 1939-1964 godah), Moscow 2005, 203. 
"completely its own master". ${ }^{4}$ Thus the council was set up as an organization lacking independence, operating on the instructions of the government and reporting to it.

The same day, a few hours later an unprecedented, historic event took place. In the Kremlin Stalin met orthodox prelates: Metropolitans Alexy, Nikolay and Sergius; the latter returned from exile in August. To their surprise, Stalin offered financial and organizational help to convene a regional synod to elect a new Patriarch after the 1925 death of Tikhon. Stalin made heartening promises regarding parishes, training of clergy, publishing Church brochures and a few other matters.

Why all this haste? The Kremlin ruler had to handle the situation that the soldiers of the Red Army experienced flourishing religious life in the territories liberated from under German occupation. On the one hand, the Church supported the defence of the fatherland and this support was vital to achieve victory in the war and for reconstruction; on the other, it had to be proved at the forthcoming Tehran Conference that there was freedom of religion in the Soviet Union. Stalin was a talented politician and he realized that the alleviation of the suppression of the Church would result in stability and foreign policy success. A section of the American public found it unacceptable for the USA to be allied with a "godless" state. ${ }^{5}$ Stalin let the world know about the change strangely enough: on 28 April 1944 the newspaper 'Pravda' published a photo of Stalin and Molotov having a conversation with a Springfield Catholic priest, Stanislaw Orlemansky. Orlemansky, an American priest of Polish origin was a simple and naïve person: he walked into the Soviet Embassy in New York and applied for a visa, because he wanted to meet Stalin and discuss with him some questions on the situation of religion. In any case, the big meeting was organized: it took place on 28 April and 4 May. The post-war political system, the Soviet-Polish relationship and the future of the Catholic Church were discussed here. Stalin conspicuously avoided giving concrete answers to the questions addressed to him and instead he spoke in generalities: "The people and the matters changed after the outbreak of the war. The war undid the conflict between state and Church. The believers stopped their resistance and the Soviet government gave up its hostile attitude towards religion. [...] There should not be any religious reprisal and there is not going to be any. The Soviet government carries out reprisals against those who persecute religion."6

The message of Stalin was clear: the Catholic Church has not been entered onto the list of enemies and the Red Army is not going to import the persecution of religion and Church that has diminished in the Soviet Union as well since 1941, the beginning of the Great Patriotic War. Did this promise reach the Catholic population of the countries occupied by the Red Army, or those Catholics, who lived within the borders of the Soviet member states? Church policy was not the most important task of the war machine, and not even the highest promise eased immediately the anxiety that religion and believers would be persecuted. Perhaps the addressee of Stalin's statements was not the population but those

4 SKAROVSKI, 205; Tatiana VOLOKITINA - Galina MURAŠKO - Albina NOSKOVA, Moskva i Vostochnaya Evropa. Vlasty i cerkov v period obsestvennih transformacii 40-50-h godov XX veka, Moscow 2008, 70.

5 lbidem, 76.

6 Arhiv Vniesniey Politiki Rossiyskoy Federacii (The Interior Politics Archive of Russian Fedeation; hereinafter referred only as AVP RF), f. 06. op. 6. p. 42. d. 548. I. 22. Minutes of the talks between Stalin, Molotov and S. Orlemansky, 4 May 1944. 
communist party-leaders, who had got to the centre of politics from its periphery, a lot of them returning home from Soviet emigration. In the spring of 1944 Stalin's directive was not less than striving for dialogue and co-operation with the Churches and encouraging believers to collaborate with the communist party. Fundamentally this course was followed in everyday life after the war, in 1945-46, though never entirely. It was curbed by the brute force of the soldiers, who got rid of their inhibitions; as well as by the measures limiting the Church, introduced by the political transformations of regime in the region - the population found these measures injurious. In addition there was a huge obstacle: the Soviet Church policy objective to make Moscow the world's religious centre. This expansive Soviet Church policy deemed the realization of the free practice of religion a failure, since it meant a conflict with the Holy See, ergo with the Catholic Churches.

Roughly simultaneously with the interview with Father Orlemansky, Stalin received the report on "The situation of the Roman Catholic monasteries in the territory of the Union of Soviet Socialist Republics". ${ }^{7}$ It revealed that Catholic life had practically ceased in the central parts of the country. The author of the report knew about two monasteries only: one of them in Moscow to serve the diplomatic corps, and another one in Leningrad. The Greek Catholic (Unitus) Church continued to exist: in West-Ukraine and Sub-Carpathia it numbered 4 million believers (1997; in 399 parishes) and it was under the authority of the Holy See.

The fate of the Greek Catholics was decided by the clash of two interests. Whilst the Vatican worried that the Greek Catholic communities would turn toward Orthodoxy, Moscow suspected that Rome wanted to make these communities the starting point of the fight against Pravoslavism; moreover, that the Vatican wanted to create a 'Catholic bloc' in East-Central Europe that would obstruct the expansion of Soviet influence. Indeed, it had been a key issue of the Eastern policy of the Vatican since the 1920s: whether to fight against the Soviets or to convert them? To stand up against atheism with the power of prayer, or to lower a religious iron curtain between East and West?

The distrust increased, because according to the information of the Council for the Affairs of the Russian Orthodox Church, at the end of the war the Greek Catholic prelates tried to restore relations with the Vatican and Pope Pius XII himself. It was an alarming possibility that the Greek Catholic Church might fully convert into Catholicism and give up the last elements of the eastern ceremony. It makes understandable the decision which was taken in Moscow to liquidate the Greek Catholic Church. In his report to Stalin, summarizing the activity of the Council for the Affairs of the Russian Orthodox Church between 1943 and 1946, Colonel G. G. Karpov mentioned the final liquidation of the Unitus Church in the Soviet Union as first point of the programme of the fight against the Vatican. The Soviet leadership drew up a dual objective as a preventive measure: the liberation of Catholicism from 'Papism' and establishing national Catholic Churches; and the return of the Greek Catholic Church to Orthodoxy. The Synod of Lviv (Lemberg) was held under pressure in March 1946, all the bishops having been arrested by then. The Synod annulled the 159596 Union of Brest (that is the communion of a part of the Orthodox Church with the Roman Catholic Church) and declared the return of the Greek Catholic Church to the Russian Or-

7 VOLOKITINA - MURAŠKO - NOSKOVA, 87. 
thodox (Pravoslav) Church. ${ }^{8}$ The process did not stop at the borders of the Soviet Union. In Romania the Romanian government ordered the communion on 1 December 1948 and, as a consequence, practically the elimination of the Greek Catholic Church. The fate of the Greek Catholics was similar in Poland and Slovakia as well and it was probable that the same future awaited the Hungarian Greek Catholics.

The foreign policy line of the Russian Pravoslav Church was absolutely clear by 1946: 1) fight against the Vatican as the number one enemy; 2) ecumenical movement as the basis of the union of Pravoslav Churches; 3) fight against certain Middle East Christian Churches that were considered "imperialist agents". These strategic goals precisely reflect Moscow's geostrategic aspirations. The particular interest in the Vatican and the ecumenical movement served the purpose of strengthening the Soviet bloc in East-Central Europe, while the close attention to the patriarchates was connected with Stalin's plans for the Mediterranean, such as Greece, Turkey and Jerusalem. ${ }^{9}$

According to a summary written in the spring of 1946, "it should be made manifest" to everyone, "who knows history", that "the political intrigues of the Vatican did harm to the attempts of the Western world to win freedom"; and "Roman Papism, as an international political organization, had to be stopped". The seven points of the document include the practical tasks proposed to achieve the goal. 1) Absolute separation of state and Church in every country; complete and unrestricted freedom of religion; every religion has the right to propaganda and diffusion of its dogmas. 2) Separation of state education from all kind of Church influence. 3) The conveyance of the estates of the Catholic Church to the population in those countries where the Catholics are in a majority. 4) Proportional representation of Cardinals and other prelates in the Roman Curia on behalf of the democratic countries. 5) Introduction of civil marriage in every country. 6) Recall of the ambassadors of the Vatican, with regard to the fact that the Vatican is not an independent state. ${ }^{10}$ 7) Equal taxation on Church property of every Church. ${ }^{11}$

Besides, the document is interesting for the sake of its date of origin, 6 May 1946. The opinion, or rather denunciation, of the Vatican and the Catholic Church by the Soviets was resolute but some indecision can be demonstrated between accusing the Vatican of potential friendship with imperialism and treating it as a possible ally. In one of his reports, describing Soviet Church policy in detail, Gyula Szekfü, Hungarian Ambassador to Moscow mentioned only refusal of the Holy See: "The recent Soviet government does not persecute the manifestations of the life of the Greek Orthodox Church; in fact it allows these to appear in public on the streets... The Soviet government keeps the Greek Orthodox Church under strict control, and according to public belief, the students, or some of the students of the newly-established Theological College are enlisted as agents of the secret

8 VOLOKITINA - MURAŠKO - NOSKOVA, 372-390; Philipe CHENAUX, L'Église catholique et communisme en Europe (1917-1989). De Lénine à Jean-Paul II, Paris 2009, 206.

9 VOLOKITINA - MURAŠKO - NOSKOVA, 91-92.

10 In the socialist countries it was considered legally evident that the Holy See does not have international subjectivity. See the summary of the standpoints on the issue: Miklós RÓNAY, Az egységesség elve a katolikus egyház külügyi tevékenységében. PhD dissertation, Corvinus University, Budapest 2006, 11-17.

11 Gosudarstvennyj Arhiv Rossiskoj Federacii (The Russian Federation State Archive; hereinafter referred only as GARF), f. 6991. op. 1. d. 77. I. 300. 9 May 1946 n. 129. Politika Vatikana vo vtoroj mirovoj vajne - summary by Leo Leman. Conclusions. 
police. While the Soviet government remarkably favours the Orthodox Church, at least on the surface, it is reserved, rigid and in fact hostile towards the Roman Church. For that very reason the head of the Greek Catholic Church is allowed to have contacts with the heads of the non-Catholic Christian Churches (e. g. the visit of the Archbishop of Canterbury to Moscow and the return of the visit by the Patriarch), whereas any contact or rapprochement with the Vatican is prohibited." 12 Szekfü also reported that the Soviet government made efforts to create national Churches and to use them for its own political purposes.

In contrast with this, some Western researchers think that the Soviet government repeatedly renewed its exploratory talks with Rome till 1947. As proof they refer to the activity of two Hungarian Jesuits, József P. Jánosi and Töhötöm P. Nagy. ${ }^{13}$ Töhötöm P. Nagy appealed to Malinovsky, Soviet marshal, the commander of the $2^{\text {nd }}$ Ukrainian Front and the political officers transferred to the country, asking protection for the Catholic organizations. They saw potentials in the network of monks reaching to Rome. Töhötöm Nagy, who was familiar with the Great Powers relations and did not recoil from risky actions, had travelled incognito to Rome five times by the autumn of 1946, once with American safe conduct, another time with a Papal passport or as a civilian but on each occasion with the knowledge of the Soviet authorities. ${ }^{14}$ Moscow even offered a certain "general agreement", to be followed by agreements between the Vatican and the East-Central European countries. Heinrich Wienken (1883-1961), who later became Bishop of Meissen, monitored in a similar way; in the post-war years he met various Soviet military officers thirty-five times (!) and subtly he reached important guarantees for the East-German Catholic Church. ${ }^{15}$ However, in Moscow the attempts - originating partly from tradition - to annul networking, proved stronger than networking itself; and with the evolution of the Cold War the former prevailed.

\section{In the Soviet Sphere of Influence}

In the interwar period the Holy See - as a supranational, supreme Church administration, leading the Catholic world - concluded concordats with some countries of the East-Central European region, such as Poland (1925), Romania (1929), the German Reich (1933), Austria (1934) and the Kingdom of the Serbs, Croats and Slovenes (1935); ${ }^{16}$ it signed modus vivendi with Czechoslovakia (1928) and concluded the Lateran Treaty with Italy (1929). In the case of the Hungarian Kingdom, a so-called 'intesa semplice' entered into force in 1927 that was not a bilateral, international treaty, this is why it is called 'simple agreement'. ${ }^{17}$ De-

12 Magyar Nemzeti Levéltár Országos Levéltára (The State Archives of The National Archives of Hungary, hereinafter referred only as MNL-OL), XIX-J-1-j-Szovjetunió-IV-270, Box No. 14. The report of Gyula Szekfü to foreign minister János Gyöngyösi, Moscow, 29 April 1946.

13 Hansjakob STEHLE, Geheimdiplomatie im Vatikan. Die Päpste und die Kommunisten, Zürich $1993,241$.

14 Országos Széchényi Könyvtár Kézirattára (National Széchényi Library, Manuscript Collection, hereinafter referred only as OSzKK), 216. f., c. u. 20, fol. 1-76, Diary notes, 1 July 1946 - 1 January 1947.

15 STEHLE, 245.

16 In the end this concordat was not enacted, because under pressure from the Serbian Orthodox Church the relating bill was not introduced to the Yugoslav Senate.

17 Fundamentally it meant that from 1918 onwards the Holy See had the right to appoint prelates but the Hungarian government was entitled to make previous comments on filling the church positions subordinate to Rome and to propose suitable people within two months after the seat had become vacant. 
pending on their legal classification, in the above-mentioned countries these documents determined the situation of the Catholic Church, the degree of its privileges and the relationship between secular power and Church. On the one hand, the principles guaranteed the independence of the Catholic Church from the state and its free communication with the Holy See; on the other hand, they determined the obligations of the state towards the Church, especially in the field of education, management of Church property (untouchable) and family law. ${ }^{18}$

What kind of an example was set by the practice followed in the countries in the Soviet sphere of influence? Apparently it was varied. Yet in general it is true that between 1944/45 and 1947/48 it was in the interests of nearly every East-Central European government to show religious tolerance to some extent and maintain connections with the Holy See. Marxism was not an insurmountable obstacle for the Holy See, since it had - and has in these days, too - diplomatic relations with Muslim countries as well. Rome distinguishes between governments and ideologies; namely, it represents an intransigent position as regards ethical or religious principles, at the same time it does not refuse to enter into negotiations with any political figure or group. However, in the long run the Papal Nunciatures were not allowed to remain in the countries of the Soviet sphere of influence, whether or not the given country was on the winning or losing side of the war.

\section{Hungary}

The liaison between Hungary and the Holy See dates back to the Middle Ages, when the Hungarian diocesan system was organized in cooperation between King Saint Stephen and the Holy See. The establishment of diplomatic relations in the modern sense arose for the first time during Rákóczi's War of Independence. Later, after the dissolution of the Austro-Hungarian Monarchy the question arose again, when the establishment of diplomatic relations with the Holy See meant a chance to escape international isolation. The Holy See established diplomatic relations with the successor states promptly: a Nuncio for the Kingdom of the Serbs, Croats and Slovenes was sent to Belgrade on 2 March 1920 and the Prague Nuncio was appointed on 7 May 1920. The first Hungarian Ambassador to the Holy See, count József Somssich presented his credentials to Pope Benedict XV and by this ceremony the official opening of the Embassy of Hungary to the Holy See took place. Lorenzo Schioppa, until then Bavarian Nuncio, became the first Nuncio to Hungary and he presented his credentials to Regent Miklós Horthy on 6 October 1920 . Between 1920 and 1945 this highest diplomatic relation enabled the peaceful negotiated solution of sensitive

18 A few examples from the remarkably rich specialised literature: Konkordat zawarty pomiędzy Stolicą Apostolską a Rzecząpospolitą Polską podpisany w Rzymie dnia 10 lutego 1925 r., Lwów 1925; Ludwig VOLK, Das Reichskonkordat vom 20. Juli 1933. Von den Ansätzen in der Weimarer Republik bis zur Ratifizierung am 10. September 1933, Mainz 1972. (Veröffentlichungen der Kommission für Zeitgeschichte, Reihe B: Forschungen, Bd. 5); Konkordátum a Szentszék és a Német Birodalom között (1933. július 20.), in: István NÉMETH, Demokrácia és diktatúra Németországban, 1918-1945 2. kötet. A "Harmadik Birodalom", 1933-1945. Összegzés és dokumentumok, Budapest 2007; GARF, f. 6410. op. 1. d. 69. I. 1-2. Proekt konkordata 1935 g. Vatikana s korolevstvom serbov, horvatov, szlovencev; Modus vivendi. Úmluva mezi republikou Československou a Svatou stolicí zjednána v lednu 1928 [online]. http://spcp.prf.cuni.cz/dokument/modus.htm (Visited: 18 February 2012); Iván POLZOVICS, A lateráni szerződés. A szentszék nemzetközi jogi helyzete, Budapest 1934 (Szt. István könyvek 114.) [online]. http://www.ppek.hu/konyvek/Polzovics_Ivan_A_laterani_szerzodes_1.pdf (Visited: 28 May 2014). 
Church policy issues, in particular the appointments of prelates and the division of the diocese that had been cut in two by the frontiers. ${ }^{19}$

Diplomatic relations were undisturbed till 1944-45. After the Second World War Hungary became part of the Soviet sphere of influence and the flexibility left to Hungarian foreign policy was reduced. "It is a serious loss for the Hungarian Catholic Church that Archbishop Angelo Rotta, Apostolic Nuncio was forced to leave his post on 6 Apr[il]", reported József Grősz, Archbishop of Kalocsa on the first conference of the Hungarian Bench of Bishops, held after the war, on 24 May 1945. ${ }^{20}$ Today we can resolve the discrepancy of the resources and pronounce that this measure was taken not by the Provisional National Government but by the Allied Control Commission (ACC) under command of the Allied (Soviet) High Command. The most convincing evidence for this is a military record of 1 March 1945 about the diplomats and representatives of foreign organizations who remained in Budapest. On the list there were only six names and the last one was Gennaro Verolino, Uditore, who was a colleague of Angelo Rotta, Apostolic Nuncio. V. M. Molotov, Minister of Foreign Affairs added the following instruction to the report: "Нужно выпроводить этих господин из Венгрии. Проследите за этим." 21 The realization of the Soviet measure is confirmed by the report of the person concerned, Angelo Rotta, Apostolic Nuncio. According to this, on 22 March 1945 two Russian employees of the Allied Control Commission ordered him to leave within three days, after the embassies of the other neutral states (Portugal, Spain, Switzerland, Sweden and Turkey) had received similar instructions. ${ }^{22}$

According to the diary notes of Töhötöm Nagy, Jesuit, even Voroshilov himself was reluctant to order the expulsion, he did not want to undertake the responsibility all by himself,

19 See the following non-exhaustive list of sources on the issue: Andor CSIZMADIA, A magyar állam és az egyházak jogi kapcsolatainak alakulása és gyakorlata a Horthy-korszakban, Budapest 1966; Péter ERDŐ, A Szentszék és Magyarország, in: Katolikus Szemle, 43, 1991, 3-4, 140-148; István ZOMBORI (ed.), Magyarország és a Szentszék kapcsolatának ezer éve, Budapest 1996; Lapo LOMBARDI, La Santa Sede e i cattolici dell'Europa Orientale agli albori della guerra fredda, Róma-Budapest 1997; István ZOMBORI (ed.), Le relazioni diplomatiche tra I'Ungheria e la Santa Sede 1920-2000, Budapest 2001; Jenő GERGELY, A magyarországi katolikus egyház és a külpolitika (1948-1990), in: Magyar külpolitikai gondolkodás a 20. században, Pál PRITZ (ed.), Budapest 2006, 39-59; Péter TUSOR (ed.), Magyarország és a római Szentszék. (Források és távlatok.) Tanulmányok Erdő bíboros tiszteletére, Budapest-Róma 2012 (Bibliotheca historiae ecclesiasticae Universitatis Catholicae de Petro Pázmány nuncupatae. Series 1., Collectanea Vaticana Hungariae. Classis 1/8.).

20 Margit BEKE (ed.), A magyar katolikus püspökkari tanácskozások története és jegyzőkönyvei 1945-1948 között, Köln-Budapest 1996, 28. The minutes of the conference of the Bench of Bishops, convened for 24 May 1945.

21 "These gentlemen must be showed to the door. Pay attention." AVP RF, f. 06. op. 7. p. 28. d. 371. I. 6. No. 44038 report of the Deputy Commanding Officer of the Red Army to V. M. Molotov, 1 March 1945 and the instructions of Molotov addressed to Dekanezov, People's Commissar of Foreign Affairs, 8 March 1945. (The names of several diplomats who remained in Budapest were not included in the list, among others that of the superior of Verolino, Nuncio Angelo Rotta. Under war circumstances it must have been difficult to identify the person of each diplomat precisely and completely.)

22 Tomislav MRKONJIĆ, Archivio della Nunziatura Apostolica in Ungheria (1920-1939). Gli archivi della Santa Sede e il Regno d'Ungheria (secc. 15-20). A cura di Gaetano Platania - Matteo Sanfilippo - Péter Tusor, Budapest-Roma 2008, 259. (Bibliotheca Historiae Ecclesiasticae Uiversitatis Catholicae de Petro Pázmány Nuncupatae. Ser. 1., Collectanea Vaticana Hungariae. Classis 1.) The author, a research worker of the Vatican Secret Archives, summarizes the events based on the most reliable sources; he quotes the reports of Rotta of 25 March 1945 and 21 April 1945, addressed to Tardini, deputy under-secretary of state, that have not been made public yet. The contents of the report accord with the contemporary diary of P. Nagy, Töhötöm S. J.: OSzKK, 216. f., c. u. 19, notebook 4, note of 23 March 1945. 
so he asked Moscow but he got a negative answer. ${ }^{23}$ In the end, on 4 April 1945, Angelo Rotta Papal Nuncio was declared 'persona non grata' for the second time, this time finally. That morning two other Russian officials visited the Nuncio and told him that no exceptions could be made. He got 48 hours to leave. ${ }^{24}$ The following day, on 5 April the Nuncio met József Grősz, Archbishop of Kalocsa in Budapest. In his diary Grősz gave a different explanation for the decision: "The reason: the recent government has no ambassadors abroad, consequently the foreign countries are not allowed to have ambassadors here. The real reason: Moscow does not want witnesses to what is going on here." 25

According to Béla Ispánki, who was found guilty of spying in the trial of Mindszenty, Rotta said to the priests present after the funeral ceremony of Cardinal Primate Serédi that in a polite letter Voroshilov had offered him to stay in Budapest "as a private person, a welcome guest" but not as a diplomat, which Rotta, while with regrets, did not accept. As far as he knew, the Soviet government insisted that in its own occupation zone only those countries were allowed to have diplomatic missions, which maintained normal diplomatic relations with the Soviet Union. ${ }^{26}$

\section{Czechoslovakia, Yugoslavia and Poland}

While the flexibility left to Hungary was reduced by the Armistice Agreement signed on 20 January 1945, the usual work of foreign representations and propaganda organs in the victorious Central-European countries was undisturbed. Diplomatic relations between the Holy See and the victorious states such as Czechoslovakia, Yugoslavia and Poland were not interrupted in law or in fact.

Czechoslovakia immediately expressed its readiness to renew diplomatic relations and the Holy See responded positively. In the summer of 1945 the Holy See officially confirmed the credentials of Raffaele Forni, the Chargé d'Affaires of the Nunciature in Prague and in the summer of 1946 the Pope accepted the credentials of the new Czechoslovakian Ambassador. ${ }^{27}$ The situation changed after the Communist takeover on 24 January 1948. Josef Beran, Archbishop of Prague could not ignore the measures against Church and religion and in the course of the preparation of the new constitution he addressed a letter to the President of the Republic, wherein he made clear that the Catholic institutions formed integral parts of Church life and asked the clarification of the legal and practical situation of these institutions, which is essential to maintain the relationship with the Holy See. He hoped for an improvement as regards the attacks against the Pope, too. ${ }^{28}$ "In return for it" he was arrested and put under house arrest and simultaneously the Czechoslovak government asked the Holy See to recall its Chargé d'Affaires. Therefore in Prague the interruption of

23 OSzKK, 216. f., c. u. 19, notebook 4, Diary of P. Nagy, Töhötöm S. J., 5 April 1945.

24 MRKONJIĆ, 260.

25 József TÖRÖK (ed.), Grősz József kalocsai érsek naplója 1944-1946. S. a. r., Budapest, n. d. [1995], 192.

26 Béla ISPÁNKI, Az évszázad pere, Abaliget 1995, 36.

27 Karel KAPLAN, Stát a církev v Československu. 1948-1953, Brno 1994, 10.

28 A katolikus egyház Csehszlovákiában, in: L’Osservatore Romano, 88, 1948, 154, 5-6. 
diplomatic relationships was accompanied by an internal purge. ${ }^{29}$

In Yugoslavia Marshall Tito started a radical, revolutionary Church policy immediately. On the territories reoccupied by the partisans 2 bishops, 243 priests, 19 clergymen, 7 friars and nuns were killed by September of 1945; 164 priests were arrested and 89 priests disappeared. ${ }^{30}$ Alojzije Viktor Stepinac, Archbishop of Zagreb was arrested in May 1945. He was accused of collaboration with the pro-Nazi Ustasha regime of Ante Pavelić in the Croat puppet state during the Second World War, when masses of Serbs and Muslims were killed; also, he was accused of approving the forced conversion of Orthodox Serbs into Catholicism. Later he was set free but he was arrested again in September 1946, after he had refused the concept of Marshall Tito to establish a Serbo-Croat National Catholic Church, independent from Rome. After a two-week trial, on 11 October 1946 he was sentenced to sixteen years forced labour with the charge of high treason and war crimes. ${ }^{31}$ After the first arrest of the Archbishop, the Vatican realized that they had to contact Tito immediately. By 1944 the Holy See recognized the royal government-in-exile but after the agreement between the partisans and the émigrés, official Vatican circles asserted that the Papal recognition of Tito's government was possible. ${ }^{32}$ Thus the main obstacle to sending a Vatican ambassador was removed. The diplomat exchange took place in 1945.

The Holy See's first Ambassador to Yugoslavia and Bishop of Florida, Joseph Patrick Hurley, arrived to Belgrade on 22 October 1945. Although his presence could not prevent the second arrest and sentencing of the Archbishop of Zagreb, the Holy See did not break relations with Yugoslavia. Years later, it was Tito who did so: he perceived as provocation that the Pope created Stepinac, who was serving his sentence, a Cardinal; this is why Silvio Oddi, the Chargé d'Affaires of the Belgrade Nunciature had to leave on 17 December 1952. ${ }^{33}$ Why had the Holy See been so patient with Yugoslavia for years? It is true, that diplomatic relations, burdened by a few conflicts, had been in danger since 1947. Marshall Tito explained to an American Protestant Church delegation that the improvement of the relationship between Yugoslavia and the Holy See depended merely on Rome but there were no signs of it and this situation could result in a break. According to Tito, the main reason for this situation was that the Catholic Church had lost its earlier influence that it had enjoyed in the period of the Austro-Hungarian Monarchy; and he also mentioned a few other reasons, e.g. economic reasons, especially the land reform that crucially affected Church property. ${ }^{34}$ However, the split between Yugoslavia and the Soviet Union took place then. It seems that precisely this split explains the reasons, because the Yugoslav separate way within the Soviet bloc gave hope to Rome that Tito was going to follow a separate way in his Church policy, too.

Similarly to Czechoslovakia, the Holy See did not have an official diplomatic representative

29 CHENAUX, 211.

30 VOLOKITINA - MURAŠKO - NOSKOVA, 488.

31 GARF, f. 6991. op. 1. d. 134. I. 74. Abstract from the article by V. IVANOVA, Demokratitseskoye preobrazovanij v Jugoslaviji, Bolsevik, 1947, 2, 49; CHENAUX, 208.

32 VOLOKITINA - MURAŠKO - NOSKOVA, 489.

33 STEHLE, 243-244.

34 GARF, f. 6991. op. 1. d. 134. I. 139-140. Marshall Tito received American Protestant leaders, 3 August 1947 (TASS report, 6 August 1947). 
in Poland - in legal terms at the time of the restoring of statehood - in 1945. However, on 20 July 1945, despite the protests of the London Polish government-in-exile, August Hlond, Archbishop of Poznań-Gniezno, Cardinal Primate, who had been interned to France by the Germans in 1942, was allowed to return. On 7 July 1945 in Rome Domenico Tardini, the Secretary of the First Section of the Papal Secretariat of State gave authorization (facultas specialis) to Hlond for jurisdiction "on the entire Polish territory" and the status of a papal legate, i.e. ambassador. ${ }^{35}$ It must be mentioned that German historians dispute the fact of the authorization, respectively its scope. This authorization - if it existed - did not state explicitly whether it applied to Poland within its 1939 borders (as the 1925 Concordat applied to these), or to the new borders, changed in 1945. In accordance with the legal practice of the Holy See, it could apply to such territories only that fell under the 1925 Polish Concordat; the Holy See considered that in the 1933 Concordat with the German Reich as well. The only exception was the Gdańsk (Danzig) Episcopate, since Gdańsk (Danzig) as an exempted episcopate (exempt) in terms of jurisdiction was placed under the Warsaw Nuncio in 1925. The Potsdam Conference (17 July 1945 - 2 August 1945) had barely closed, when on 15 August Cardinal Hlond, referring to the special authorization received from the Holy See, appointed five Polish prelates as Apostolic Administrators for the former German Reich territories that were annexed to the Polish state, east from the Oder-Neisse border. Despite his efforts, the Warsaw government did not consider his measure as recognition of the new borders of the Polish state and the Provisional Government by the Vatican. The Holy See did not join the decision of the Potsdam Conference, with which the Allies withdrew their recognition from the Polish émigré government in London and they established diplomatic relations with the Warsaw Provisional Government instead.

In return the Polish Government in Warsaw did not recognize the appointment of the Apostolic Administrators and on 14 September 1945 it denounced the 1925 Concordat, arguing that it was the Holy See that had one-sidedly infringed it with the appointment of an ethnic German bishop, respectively an administrator as heads of Chełmno (Holm, Kulm) and Poznań-Gniezno, Polish episcopates. ${ }^{36}$ The background of the short justification is the fate of Poland during the World War. In the autumn of 1939 Gdańsk (Danzig) Free City, later the Western territories of Poland, were annexed to the German Reich and the Catholic Church structure was also adversely affected, because due to the occupation, certain Church Governance districts were disannexed. In the merged territories vigorous Germanization started, including the destruction of the Polish Church structure. After the Bishop of Chełmno diocese had gone into exile, in December 1940 the Holy See entrusted the Bishop of Gdańsk (Danzig), Karol Maria Splett of German origin, famous for anti-Polish feelings, with the governance of the diocese as Apostolic Administrator. With this measure Rome violated the Concordat, because according to its Article 9 - similarly to the Czech and Romanian agreements - not a single district of the Polish Republic was allowed to be under the authority of such a bishop, who was staying outside the borders of the Polish state. According to the Provisional Government of Poland, with the appointment Pius XII practically recognized Hitler's plunders in Poland. The division of the Poznań-Gniezno

35 Jan KOPIEC, Polen, in: Kirche und Katholizismus seit 1945. Band 2. Ostmittel-, Ost- und Südosteuropa, Erwin GATZ (ed.), Paderborn-München-Wien-Zürich 1999, 103.

36 STEHLE, 239. 
episcopate was also seriously criticized. Namely, the Vatican, worrying about the expulsion of the Polish population and the annihilation of the Church, appointed an Apostolic Administrator for the German nationality (at first Józef Paech, later Lorenz Breitinger), and separately, another one for the Polish nationality (Bishop Walenty Dymek). ${ }^{37}$ In 1945 it was interpreted as a violation of Article 9, because the Catholic hierarchy of the Polish Republic could not have been divided on the basis of nationality, except for the ritual. ${ }^{38}$ In this justification the sensitivity of Poles can be perceived. The inviolability of borders was of the greatest importance for the country, which regained its statehood after the First World War - likewise for the newly formed Czechoslovakia. This is why a provision was included in the agreements between these countries and the Vatican that the Church Governance division must be consistent with the borders, and the centres of the diocese must be within the borders.

However, there could be a different interpretation as well: that the Holy See acted the same way in Poland as in Northern Italy during the Nazi occupation. Namely, the Vatican did not want to collaborate with the current regime, because this could have been explained as recognition of the Nazi occupation, so it refrained from the appointment of new bishops and entrusted Apostolic Administrators with the control of the episcopates. In Poland the areas concerned had mixed populations and were near the German border, therefore the Administrators were chosen from the German ethnic group. Thus using the disputed and really controversial war-time appointments as an excuse, the Warsaw government cancelled the Concordat and broke the diplomatic relationship, which foreshadowed the outset of the merciless laicization.

The 26 September 1945 issue of the "L'Osservatore Romano" published a communiqué about the issue of the Polish Concordat and tried to rebut the accusations against the Vatican. It argued that the measures concerning the Gniezno and Poznań episcopates were taken in an extraordinary situation ensuing from the German occupation and were necessitated by the requirement that the believers needed a spiritual leader. Subsequently, the communiqué briefly recited the violations of the terms of the Concordat by the Provisional Government of Poland: the episcopate, the priesthood and the believers were forbidden from direct contact with the Holy See (Article 2 of the Concordat); bishops and priests were arrested (Articles 20 and 22); private individuals and Church institutions were not paid the subsidies (Article 24). About the recognition of the Provisional Government of Poland by the Vatican the communiqué states as follows: "the fact that the bilateral agreement was violated, excludes the assumption that they expect recognition." 39 Indeed Rome did not yield: the Nuncio in the person of Archbishop Filippo Cortesi was sent to the Polish government-in-exile in London and not to Warsaw. To be more precise, the Vatican did not change the person of the Nuncio, since Cortesi had administered this office since 1936 but after the outbreak of the Second World War he was forced to live in Poland. He held the title of Nuncio until his death in 1947. After his death the Holy See did not appoint a

37 Jerzy KŁOCZOWSKI - Lidia MŰLLEROWA - Jan SKARBEK, A katolikus egyház Lengyelországban, Budapest 1994, 346-351. (Ecclesia Sancta 8.)

38 AVP RF, f. 56b. op. 6. p. 45. d. 60. The communique of the Government of Poland about the relations with the Vatican (TASS report, Warsaw, 14 September 1945); VOLOKITINA - MURAŠKO - NOSKOVA, 512-513.

39 AVP RF, f. 56b. op. 6. p. 45. d. 60. News agency report, 27 September 1945. 
new Nuncio; this position has now been filled again since 1975, at first by Archbishop Luigi Poggi.

With the termination of the Concordat the Communist-dominated government deprived Catholic Poland of the instrument of cooperation with the Vatican and this was alarming for the other Central and East-European countries, where conditions were similar. The Polish Catholic Church was deprived of its status guaranteed by international law, simultaneously, no governmental approval was necessary for the appointment of bishops. Presumably, sending a Nuncio to Warsaw, thereby recognizing the new government of Poland, would not have saved the Catholic Church from later conflicts. Nevertheless, the maintenance of the relationship would have probably reduced the Soviet pressure on the country, and perhaps those national communists would have been strengthened, which regarded the 1950 compromise agreement with the Church not only as a manoeuvre.

Under Pius XII not only the Polish government-in-exile in London but also the Lithuanian government-in-exile could continue to operate their Vatican missions, so from the point of view of the Vatican both countries had legally valid diplomatic missions there. The situation changed in 1958, when according to long-term custom, new credentials were necessary to the new Pope (John XXIII) and these were not accepted from the governments-in-exile by the Secretariat of State. Supposedly, the underlying cause was a consultation between Pope John XXIII and Polish Cardinal Wysyński; as a consequence the Pope decided to refuse the credentials issued by the Polish and the Lithuanian governments-in-exile. Thus the representation of the two emigrant governments to the Vatican practically terminated. Nevertheless, Poland and Lithuania were not erased from the list of names of diplomatic missions but there was neither ambassador nor envoy or any other diplomatic rank indicated under the names of these countries. Only a Chargé d'Affaires was indicated but after the colon a horizontal line showed that in reality this position was not fulfilled. That was all that the Polish and Lithuanian emigrants, seriously supported by the Americans, could achieve. "If all this proves to be true, a typical diplomatic solution of the Vatican will be added to the documentation of clerical hypocrisy", remarked the Hungarian Ambassador to Rome. ${ }^{40}$ The Vatican did not recognize the ambassadorial rank of the representatives of the two governments-in-exile and they were regarded and addressed simply as managers (gerente); besides, the Holy See did not send representatives to these governments (until 1972 Kazimierz Papée was the representative of the Polish government-in-exile to the Holy See) ${ }^{41}$ Diplomatic relations were re-established only with the collapse of the Soviet Empire, in 1989.

\section{Romania}

After Romania switched sides to the Allies on 23 August 1944, the king remained in office, and the members of the diplomatic corpses accredited to him also did so, with the suspension of their diplomatic rights. Thus the country had an opportunity to maintain its representation in every neutral country. Accordingly, the Italian Andrea Cassulo, who had 40 MNL-OL, XIX-J-1-j-001221 1945-64. Italy (Box No. 10, item 5/c). The report of Gyula Simó, Ambassador to Rome, 28 January 1958.

41 KOPIEC, 104. 
been Nuncio to Bucharest since 1936, continued to serve there. What was unimaginable in the case of the Russian Orthodox Church, in the case of the Orthodox Romanians was not: (in the expectation of power) the two, earlier rival Christian Churches were able to form an anti-government and anti-Soviet front. It was suspicious that at the beginning of 1946 Apostolic Nuncio Andrea Cassulo and Alexandru Theodor Cisar, Archbishop of the Bucharest Latin Archdiocese visited the Roman Patriarch, Nicodim Munteanu, who was a militant anti-communist. According to certain sources, Cassulo and Cisar presented Patriarch Nicodem with an anniversary medal from the Pope and offered him the title of "the Cardinal of the East", thus enabling him to negotiate with Rome on behalf of all the Eastern-European Orthodox Churches. ${ }^{42}$ The authorities tried to compromise Cassulo in connection with the judicial proceedings against Marshall Ion Antonescu, who was executed as war criminal. Consequently, Cassulo practically became persona non grata in Romania and in 1946 the Holy See appointed Internuncio Gerald Patrick O'Hara, earlier Bishop of Savannah, as his successor. Despite the difficulties, until his departure in March 1947 Nuncio Cassulo protected the safety of the Roman Catholic Church and maintained a relationship with the Romanians, especially with politicians and diplomats, while the Romanian officials - like gradually everywhere in East-Central-Europe - presumed that the Apostolic Nunciature in Bucharest was a sort of intelligence agency of the Vatican. From the summer of 1947 remarkably many priests were accused of spying; moreover, after the departure of Cassulo the authorities suspected the new Internuncio, O'Hara and his colleagues, Guido del Mestri and John C. Kirk as foreign agents. ${ }^{43}$

On 17 July 1948 Decree No. 151, consisting of one article only, denounced the Concordat between Romania and the Holy See. "The Concordat concluded between the Pope and Romania on 10 May 1927, as well as the additional agreements in connection with the entry into force of the Concordat, lapse with the announcement of the present law. From this date the mandatory nature and application of the Concordat and the additional agreements and measures cease. The law of 12 June 1927 that ratified the Concordat, as well as the additional laws confirming the agreement, lapse. "44 The relationship between the Catholic Church of Romania and the Holy See was fundamentally cut by Article 4 of the Law on Religion, accepted on 4 August; it stipulated that religious communities or their leaders are banned from maintaining foreign relations, unless they have permission from the Ministry of Religion, through the Foreign Ministry. In 1950 Nuncio Gerald Patrick O'Hara was expelled from Bucharest on the charge of espionage, which is an entirely new element in the justification of the cessation of the East-Central European Nunciatures. If he had stayed there, without doubt he would have been among the victims of the show trials that spread in those days.

42 Cristian VASILE, The Apostolic Nunciature in Romania at the beginning of the communist regime, in: Instituto Romeno Di Cultura e Ricerca Umanistica (Venezia) Annuario Vol. 4, Şerban MARIN - Ion BULEI - Rudolf DINU (eds.), Bucarest 2002, 256-257.

43 Ibidem, 259.

44 GARF, f. 6991. op. 1. d. 733. I. 69. The legal status of the Churches in Romania. On top of the page in handwriting: Из журнала Ведомости польск[ой] пр[авославной] ц[ерк]ви 6-12, 1948 г. стр. 39. 


\section{Albania, Bulgaria}

After the Second World War, in those states of the Eastern bloc where the Muslim or Orthodox religion was in a majority, the Diplomatic Missions of the Holy See worked only for a short time - similarly to the countries with a Catholic tradition. Leone Nigris, the Apostolic Delegate to Tirana was expelled in May 1945, and in the course of time Enver Hoxha's Albania became the first "atheist state" as declared in the constitution. In Bulgaria, which was also defeated in the war, the Holy See had a Permanent Representative without diplomatic status since 1925, at first as Apostolic Visitor, since 1931 as Apostolic Delegate. Until 1934 Agostino Roncalli, the later Pope John XXIII held this position and he was succeeded by Giuseppe Mazzoli; after his sudden death (8 December 1945) the duties were performed by a provisional delegate, who was not allowed to return after one of his trips abroad. ${ }^{45}$ The Allied Control Commission approved the re-establishment of relations with Austria, as the sole country from among those under the control of the ACC. Thus a Papal Legate continued to serve in Austria and an Austrian Ambassador in the Vatican, although the debate continued between the two sides on the validity of the 1934 Concordat.

\section{Attempts at the Normalisation of Diplomatic Relations Between Hungary and the Holy See ${ }^{46}$}

With the expulsion of Angelo Rotta in April 1945, the communication between the Hungarian Bench of Bishops and the Holy See became more difficult. Soon after József Mindszenty was appointed Archbishop of Esztergom, in his letter of 10 October he requested the re-establishment of diplomatic relations with Pope Pius XII. ${ }^{47}$ The two most influential personalities of the Secretariat of State approached the request constructively, Montini even said: "The Holy See is looking forward to the day, when the Hungarian government will request the re-establishment of the Nunciature. Although it is true that His Excellency the Nuncio was expelled by the Soviet and not by the Hungarian government, it is the latter that has to take the first step, because it knows whether the Soviets will expel the representative of the Holy Father again or allow him to enter the country. Moreover, the government can give the guarantees asked by the Holy See once again, that is the immunity of the members of its diplomatic corps, the extraterritoriality of the building and free contact with the Vatican. The Holy See does not claim more or better housing and services

45 Gerhard FEIGE, Bulgarien, in: Kirche und Katholizismus seit 1945, II. Ostmittel-, Ost- und Südosteuropa, Erwin GATZ (ed.), Paderborn-München-Wien-Zürich 1999, 58; http://www.catholic-hierarchy.org/bishop/bmazzoli.html (Visited: 28 May 2014)

46 Margit BALOGH, A szentszéki-magyar kapcsolatok a koalíció (1945-1949) éveiben, in: Magyarország és a római Szentszék. Magyarország és a római Szentszék. (Források és távlatok.) Tanulmányok Erdő bíboros tiszteletére, Budapest-Róma 2012 (Bibliotheca historiae ecclesiasticae Universitatis Catholicae de Petro Pázmány nuncupatae. Series 1., Collectanea Vaticana Hungariae. Classis 1/8.), 367-426.

47 Prímási Levéltár, Esztergom (Esztergom Primatial Archives; hereinafter referred only as EPL), Processus Joseph Card. Mindszenty, V-700/27, fol. 248, József Mindszenty's letter to Pope Pius XII, Esztergom, 10 October 1947. The same in handwritten draft: V-700/32, fol. 2. (Duplicate: Állambiztonsági Szolgálatok Történeti Levéltára [ÁBTL, Historical Archives of the Hungarian State Security] 3.1.9. V-700/27. and 32.) 
than which is afforded to the other Hungarians at present." 48

The Prince Primate did not wait for the official answer and on 27 October he informed Prime Minister Béla Miklós de Dálnok that he himself wanted to invite the Holy See to re-establish diplomatic relations urgently - as he had done so by then. The reply of the government was not negative. ${ }^{49}$ Following the National Assembly elections of November 1945, the new Prime Minister, Zoltán Tildy, as soon as he had introduced his government in the Parliament, paid a visit to Prince Primate József Mindszenty, accompanied by Priest Béla Varga, politician of the Smallholders Party - that was reminiscent of bygone days. The Prince Primate explained that he opposed the issue of the republican form of government being raised, and if that could not be postponed, he would propose a referendum. His guests agreed with him and then Tildy conveyed the government's wish "to establish diplomatic relations with the Vatican as soon as possible". ${ }^{50}$

The first steps were taken towards the normalisation of the relationship. Nevertheless, the Hungarian government did not seize the opportunity to receive the Nuncio in the more favourable atmosphere in the period between the armistice and the peace treaty; and did not convey sufficiently the wish of the entire Catholic society to the Allied Control Commission. At the same time, the Prince Primate did not leave any room for doubts that he wished to take the initiative.

The Prince Primate had the opportunity to intermediate during his two visits to Rome. The first visit took place between 29 November and 13 December 1945, the second one between 18 February and 18 March 1946. In his memoirs he does not separates the two visits regarding the forming of diplomatic relations, although in the meantime his judgment changed considerably. Mindszenty made a diagnosis of Hungarian Catholicism on the first papal audience. "When I said that the Prime Minister of the new government requested the re-establishment of diplomatic relations with the Holy See, he wanted to take action immediately in order that Angelo Rotta depart for Budapest." 51 The memoirs continue with Mindszenty's doubts: "But his face darkened when I revealed my suspicions about this case." ${ }^{2}$ Actually, Mindszenty also mentioned his suspicions when he wrote about the above-mentioned visit by Tildy. It occurred to him that "the Russians wanted to make a good impression on the Vatican with this proposal", and wanted him to convey the good

48 OSzKK, 216. f., c. u. 19, fol. 300-303, The Diary of P. Nagy, Töhötöm S. J. Rome, 23 October 1945; ibidem, c. u. 48, fol. 5, "Jelentés a 2. római tartózkodásom alatt elért eredményekről (1945. október 11-november 19.).", Rome, 21 November 1945, signed as "Alessandro" [=P. Nagy, Töhötöm], addressed to Prince Primate József Mindszenty.

49 Politikatörténeti és Szakszervezeti Levéltár (The Archives of Political History and Trade Unions), 274. f., c. u. 7/247, fol. 39-42.

50 BEKE, 66. The minutes of the Conference of the Bench of Bishops, convened for 20 December 1945. (In the minutes 13 November 1945 is mentioned as the date of the meeting but it is a typist's mistake, because as Prime Minister Tildy could not visit Mindszenty then, since he came into office only two days later, on 15 November. In other sources, for example in the Memoirs of Mindszenty, the Prime Minister's visit is correctly dated as 16 November.)

51 József MINDSZENTY, Emlékirataim, Budapest 1989, 109.

$52 \mathrm{lbidem}$ - According to the special literature, the quoted contents are also attached to the first visit. See for example: Jenő GERGELY, A 20. században (1918-1995), in: Magyarország és a Szentszék kapcsolatának ezer éve, István ZOMBORI (ed.), Budapest 1996, 276; LOMBARDI, 103; GERGELY, 2006, 79. 
news in order to counterbalance his reports, revealing anti-religious manifestations. ${ }^{53}$ In the scene of the papal audience, as reconstructed a few decades later, the events of the two visits are merged. In December 1945 Mindszenty might have had some faint suspicion but he had no real reason to question the reliability of the new Hungarian government and that it served Hungarian interests. Two days after his return from Rome he informed the Prime Minister that the Vatican welcomed the initiative to re-establish diplomatic relations, "there was no impediment to the re-establishment of relations" on the behalf of the Holy See, and it considered sending Archbishop Angelo Rotta, former Nuncio to Budapest. "The Holy See assumes that the Nuncio fulfils the same role and position in the diplomatic corps as in the past and everywhere else" 54 - this sentence referred to the title of 'doyen', the precedence in the diplomatic corps, a role which became a tradition in the Catholic countries. The gesture that they wanted Rotta to return to Budapest reflected the viewpoint of the Holy See: diplomatic relations are continuous, did not break 'de iure'.

The Prince Primate expressed similar views to the members of the Bench of Bishops. Returning from Rome after his first visit, he did not say anything regarding his misgivings; he rather urged the re-establishment of diplomatic relations. His explanation of world politics was the only concept he did not share with the public: "nothing has changed in the strained relations between the Vatican and the Soviet Union and there is no chance of it for the time being. The Vatican has great missionary expectations for the distant future." 55 Töhötöm P. Nagy, Jesuit, who had been to Rome a few weeks before the Prince Primate, viewed and assessed the Eastern-European policy of the Vatican somewhat differently. His news came mainly from the confidants of the Pope, among others from another Jesuit, P. Robert Leibert, the private secretary of Pope Pius XII. He said that "the Vatican wants to establish relations with Moscow under any circumstances". Over time it set several diplomatic channels into motion: first the Internuncio of Ankara years ago, then the representative of the late American President, Roosevelt and at present both sides are trying to come closer together through Stockholm. Therefore it is unpleasant for Rome if certain prelates aggravate the situation $^{56}$ - and although unsaid, it was a reference to the electoral circular ${ }^{57}$

53 MINDSZENTY, 105.

54 "...l informed the Vatican about the decision of the government of the Hungarian Kingdom to attempt the re-establishment of diplomatic relations with the Vatican." According to the letter, the Vatican do not see any impediment and they consider sending Angelo Rotta. EPL Processus Joseph Card. Mindszenty, V-700/27, fol. 247, The letter of József Mindszenty to Prime Minister Zoltán Tildy. Esztergom, 15 December 1945. (The handwritten draft of the same letter: ÁBTL 3.1.9. V-700/32, fol. 1.); EPL V-700/27, fol. 246 and ÁBTL 3.1.9. V-700/32, fol. 4. [11.], No. 4045/1945 letter of József Mindszenty to Foreign Minister János Gyöngyösi. Budapest, 20 December 1945. Typewritten copy.

55 BEKE, 65. The minutes of the conference of the Bench of Bishops, convened for 20 December 1945, No. 2 item on the agenda.

56 OSzKK, 216. f., c. u. 19, fol. 313-314, The diary of P. Nagy, Töhötöm S. J. Rome, 1 November 1945.

57 The pastoral letter, released on 18 October 1945 on the occasion of the approaching National Assembly elections, was signed by the Primate but it was published on behalf of the Hungarian Bench of Bishops. It directed justifiable and serious criticism at the developments in domestic politics, implicitly calling on believers to support the Smallholders; thus it promoted the unification of the civic forces. This pastoral letter was the first to reveal publicly the constraints and crisis of the Hungarian democracy. As reasons for the crisis it indicated the disregard of natural law, denial of God, the Communist party policy and the abuses by the police. On account of its contents, the political parties regarded the pastoral letter as an unprecedented intervention in politics and the electoral campaign. See the published text of the pastoral letter: József VECSEY (ed.), Mindszenty okmánytár. Pásztorlevelek, beszédek, nyilatkozatok. Vol. 1. Mindszenty tanítása. Munich 1957, 70-76. 
of the Primate, which was criticized by the political parties. The Father reached a similar conclusion after the Papal audience of 23 October: the Vatican adopted the pursuit of a 'modus vivendi' with the Soviets. ${ }^{58}$

Nevertheless, Pius XII did not have illusions about the nature of the Soviet system and its objectives of conquering Central- and Eastern Europe. The danger of the spread of communism, the responsibility towards the Catholic believers of Russia and the lack of confidence in Stalin's words urged him to seek an effective remedy against the danger threatening Western - Christian Civilization. Nevertheless, the Eastern policy of the Holy See was differentiated and complex and it did not make a total commitment; it tried to retain its neutrality, balancing between the two political blocs. "The nature of the reaction against communism is ethic and religious in the first place, and political in the second place" - can be read in the memorandum, consisting of instructions for the Nuncios, prepared by the Secretariat of State in January $1948 .^{59}$

It seemed for outsiders that there was an agreement and that the Nunciature could restart its work soon. Meanwhile another, apparently minor problem arose: the question of the Nuncio's being the 'doyen'. Since 1815, when in Vienna an international system of diplomatic ranks was established, the Ambassador of the Pope - who was called 'decanus' or 'doyen', i.e. first or senior - has taken precedence in the diplomatic corps, irrespective of the date when he presented his credentials. In Catholic countries this tradition has always been kept and usually in other countries, too. After 1945 the first foreign diplomat appointed to Hungary was none other than Grigory Maksimovich Puskin, Soviet Ambassador... All of a sudden the usual diplomatic choreography became a matter of prestige for an atheist empire and the Catholic Church. ${ }^{60}$ The Vatican could have been generous and stated: the re-establishment of diplomatic relations with Hungary does not depend on this matter. To all appearances the only open point was the timing of the re-opening of the Nunciature in Budapest. József Mindszenty visited Rome for the second time when he was elevated to Cardinal. Then he submitted a written report on the Hungarian situation, in which he repeated the Hungarian government's desire to "the re-establish public diplomatic relations between Hungary and the Holy See" but this time he expressed his misgivings as well. At least the answer, dated on 14 March, clearly refers to it: "I guess I do not have to say that His Holiness agrees with such a desire" - started Montini the answer, agreeing with the essence; then after a Baroque-style period he responded to the reservations: "since you had your doubts, it must be examined whether there are any obstacles in connection with the pro-

58 OSzKK, 216. f., c. u. 19, fol. 300-303, Diary of P. Nagy, Töhötöm S. J. Rome, 23 October 1945, ibidem, c. u. 48, fol. 10, „Jelentés a 2. római tartózkodásom alatt elért eredményekről (1945. október 11-november 19.)”, Rome, 21 November 1945, signed as "Alessandro" [= P. Nagy, Töhötöm], addressed to Prince Primate József Mindszenty.

59 CHENAUX, 173-174.

60 There has been a similar case when in Germany in 1929, after the resignation of Nuncio Pacelli, Krestinsky Russian Ambassador became Senior. With the appointment of the new Nuncio, the question arose whether he could be considered 'decanus natus', which was refused only by Japan and Soviet Russia. (The situation had an added piquancy, because the Russian Ambassador, who aspired to be a 'doyen', represented such a country, Soviet Russia, which was not recognized by some of the states that had diplomatic missions in Germany.) See: Zsuzsa B. LŐRINCZ (ed.), A vatikáni magyar követ jelenti..., Budapest 1969, 195. 
posal."61

Mindszenty lost confidence in the sincerity of the intentions of the new government in February of 1946; there had been no sound reasons for it earlier, at the end of 1945. The events before his second visit to Rome radically changed his opinion about the government: in his view the codification of the republican government was a coup d'état. Law I of 1946 was enacted by the National Assembly on 31 January 1946: the monarchy was abolished and Hungary was declared a republic. Mindszenty thought that the smooth relationship between state and Church was endangered; in his view the ideal form of government had been and was the monarchy, in which the constitutional role of the Prince Primate was rooted, too. Thus we think that the Prince Primate's misgivings regarding the re-establishment of the Nunciature originated in the adoption of the republican government. Although in his Memoirs he did not give full details of his suspicions, it is clear that according to him, the Hungarian government tried to make a good impression on the Vatican by the re-establishment of the Nunciature. Mindszenty thought that both the Soviet and the Hungarian government wanted to use the accreditation of a Nuncio for their self-justification, disguising their anti-religious intentions. Giving his opinion, Mindszenty practically dissuaded the Pope from the immediate re-establishment of diplomatic relations, whilst in the long term he was interested in unhindered contact with the Holy See, because in the absence of a Nuncio the Hungarian Church remained isolated from Rome.

It seems that by the spring - summer of 1946 the Vatican had lost its first enthusiasm towards the revival of relations and they worried that the government's letter of intent had been addressed to Esztergom instead of Rome. It was interpreted as meaning that the government did not take a substantive initiative.

Ultimately, the re-establishment of diplomatic relations with the Holy See was hindered not only by political reflections - especially not by those of Hungarian domestic policy - but by considerations of Soviet power and ideology. The ACC gave permission to establish diplomatic relations with different states, one after the other: by the summer of 1946 with Italy, Romania, Bulgaria, Switzerland and the Spanish government-in-exile but not with the Holy See. Thus the Hungarian Embassy in Rome could establish a connection with the Holy See indirectly only, through the Holy See Ambassador accredited to Italy. ${ }^{62}$

The events of Hungarian domestic policy during the first half of the year 1946 indicated the end of religious tolerance. On 4 July 1946 László Rajk, Minister of Interior ordered the dissolution of the ethico-religious associations, thus paralyzing denominational youth work. The most important victim of the measure was the KALOT (Katolikus Agrárifjúsági Legényegyletek Országos Testülete, National Association of Rural Catholic Young Men) and its Jesuit leaders believed in the possibility of a 'modus vivendi' until the last moment. "I've

61 EPL, Processus Joseph Card. Mindszenty, V-700/30, fol. 80-81, G. B. Montini substitutus, letter No. 110.941. to Cardinal Archbishop József Mindszenty. Vatican, 14 March 1946. Original, autograph. In Hungarian; concerning style it is different from the version published in our paper. EPL, Processus Joseph Card. Mindszenty, V-700/30, fol. 79-80; carbon copy, ibidem, V-700/27, fol. 249. (Duplicate: ÁBTL 3.1.9. V-700/30. and V-700/27.)

62 MNL-OL, XIX-J-1-u, Documents of János Gyöngyösi, c. u. 6 (Box No. 24). "The memorandums of Foreign Minister Gyöngyösi." Memorandum on the visit of Augusto Assettati, Italian Chargé d'Affaires. Budapest, 23 October 1946. 
got two requests: the readmission of the Nunciature and an invitation for me to Moscow"63 - was written in his diary by Töhötöm Nagy, Jesuit priest, who was in Hungary again. To this end on 6 September 1946 he had a long talk with Boris Pavlovich Osokin, the deputy political adviser of the ASS. Earlier the Soviet political officer had explained on several occasions that he considered Mindszenty the vanguard of the Vatican, who followed the directives of Rome. According to Osokin, the Primate would regard the readmission of the Nunciature as his own success and this advantage should not be granted to him. "Everyone would say that the Russians yielded to the rigorousness of the Prince Primate. They will never do this, though." 64 On the Jesuit-Soviet talks the matter of the Nunciature arose for the last time on 18 October 1946 and it became obvious that the modus vivendi was not on the agenda anymore. A few days later Töhötöm Nagy left Hungary. In the view of the Holy See the pro-Moscow period of reflection had ended with a failure.

In 1945-46 the Hungarian Catholic Church pushed hard the settlement of diplomatic relations but from the second half of 1946 its political reality decreased dramatically, partly because the divide widened between the Prince Primate and the government. Mátyás Rákosi, Deputy Prime Minister, the head of the Hungarian Communist Party said that the Nunciature must not return, because "then there would be two Mindszentys in the country instead of one", whose provocative gestures would be supported by the Vatican. ${ }^{65}$ The Holy See did not put a lot of effort into revitalising the relationships, either. While in 1919 it showed willingness to establish diplomatic relations with Hungary before the signing of the Trianon Peace Treaty, now it cautiously waited. The presence of the Red Army gave rise to mistrust and it increased when the brutality of the Soviet Church policy became manifest in relation to the elimination of the Ukrainian Greek Catholic Church, which was completed by 1947. The following turning point in the relationship between the Holy See and Hungary was when some tentative steps were taken in the first half of 1947 in order to restore the authority of the government, which was undermined in the dispute on facultative religious instruction. At first István Kertész, Ambassador, later László Tóth, Rector of the University of Szeged was entrusted with the task of sounding out the possibilities.

The re-establishment of formal relations between the Holy See and the Vatican, desired both by the Hungarian government and a large section of the public, extended beyond Hungarian domestic policy; it reflected the conflict of interests of the great powers and met with intense resistance from the Soviet politicians. According to the French Ambassador to Budapest, the implacability of the Soviets originated in their antipathy towards the head of the Hungarian Catholic Church, Price Primate József Mindszenty, because the Primate was the leader of the opposition not only against the Hungarian government and communist influence but also against Soviet control. "The Cardinal plays this dangerous role without moderation; he is more and more careless about his language and behaviour and causes problems for the Hungarian government, which is saddened at the thought that the Vatican put this prelate at the top of the Hungarian Catholic hierarchy in a defeated, devastat-

63 OSzKK, 216. f., c. u. 20, fol. 14, The Diary of P. Nagy, Töhötöm, 1 September 1946.

64 OSzKK, 216. f., c. u. 20, fol. 21, The Diary of P. Nagy, Töhötöm, 1 September 1946.

65 OSzKK, 216. f., c. u. 50, "Jelentés a magyar katolicizmus helyzetéről. 1946. november 5-ig bezárólag." Written by Nagy, Töhötöm S. J., Rome, 12 November 1946. 
ed and occupied Hungary." ${ }^{66}$ In addition there was another problem, comparable in gravity to all this: the apparent pro-American attitude of the Vatican; or the other way round, the rapprochement of the Protestant-majority United States with the Vatican that was demonstrated in different ways. For example, in 1946 Mindszenty travelled to the Consistory in Rome by an American military aircraft; Hlond, Polish Cardinal held a press conference in the USA Embassy to Warsaw ${ }_{i}^{67}$ and often American citizens were the heads of the Vatican Missions in the countries behind the Iron Curtain, such as Hurley, Nuncio to Belgrade and O'Hara, Nuncio to Bucharest. Thus they were not only under the protection of the Holy See but under the protection of the United States as well, which had considerably greater power and influence. Despite these manifestations of cordiality, before 1948 the Holy See and the United States did not have diplomatic relations. Nevertheless, because of the common communist enemy, the rapprochement of Rome and Washington was advantageous: the Pope was the moral leader of the anti-communist front, while America represented the political power, capable of significant resistance to Bolshevism.

In the circumstances it seemed hopeless to persuade the Soviets that the presence of a Nuncio, who was endowed with political awareness, could only improve the situation. In the French diplomacy's views the Soviet authorities thought the opposite: namely, "there would be more difficulties if a more flexible and enlightened Nuncio joined the obstinate and narrow-minded Cardinal". ${ }^{68}$ That is why the news spread in diplomatic circles that Ambassador István Kertész had tried to persuade the Vatican to appoint Mindszenty to Curial Cardinal and with this at least the main personal impediment to the establishment of relations would be removed. The issue remained on the agenda until December of 1948. However, the Secretariat of State had up-to-date information about the political crisis in Budapest, which ended with the enforced resignation of Prime Minister Ferenc Nagy, whose party, the Independent Smallholders Party was at an advanced stage of decomposition. In this uncertain internal situation all efforts towards an agreement were illusory and would not have justified the removal of the Cardinal Archbishop.

The situation changed when the Peace Treaty entered into force on 15 September 1947. Under the new circumstances the country was represented by László Velics, Hungarian Ambassador to Rome, because his predecessor, István Kertész had emigrated to France after the resignation of Ferenc Nagy. All efforts to start communication with the Vatican and re-establish diplomatic relations with the Holy See had failed by this time and envoys had been sent in vain. Pope Pius XII had known Velics personally for two decades; they had met in Germany where the future Pope served as a Nuncio, while Velics was the Secretary of the Hungarian Institute in Munich as well as a Consul General. He was chosen for the position of the Ambassador to Rome because of the supposedly amicable nexus. There were very high expectations of him, so the subsequent failure was really disappointing.

66 Archives du Ministères des Affaires étrangères (Archive of the Ministry of Foreign Affairs; hereinafter referred only as AMAE), Série: Europe, 1944-1960, sous-série: Hongrie, dossier: 18. Questions religieuses, 1944-1949. 13v. The report of Henry Gauquié, French Ambassador to Hungary, No. 157/EU, 16 April 1947.

67 MNL-OL, XIX-I-1-v, Documents of Ortutay, 3-c item/9 (Box No. 38) Press material, Die Weltwoche, 3 March [1948 or 1949].

68 AMAE, Série: Europe, 1944-1960, sous-série: Hongrie, dossier: 18. Questions religueuses, 1944-1949. 13v. The report of Henry Gauquié, French Ambassador to Hungary, No. 157/EU, 16 April 1947. 
In October of 1947 Velics presented his credentials and almost immediately sought to inform the Holy See: "with the cessation of the ACC in Hungary, we have a free hand to establish diplomatic relations. All relevant political factors wish the re-establishment of our diplomatic relations with the Vatican as soon as possible." 69 He waited for the response of the Holy See confidently and calmly, and he was very disappointed by the definite answer that he got on 5 November 1947: "the Holy See does not believe that the time has come for starting negotiations with the Hungarian Government and for the re-establishment of diplomatic relations. It is of the opinion that the Hungarian Government does not have full freedom of action, although through no fault of its own."70 The Pope did not even receive him on an audience, arguing that he was not allowed to receive an ambassador accredited to the Italian Republic. ${ }^{71}$ It was an ill-concealed refusal of any rapprochement.

In January of 1948 iterative, unofficial negotiations started between the Hungarian Government and the representatives of the Catholic Church. Gyula Czapik, Archbishop of Eger recorded his impressions on the first meeting: "Perspective goal and title: the Concordat. Immediate goal: its preparation and laying down the foundations of the relationship could be a modus vivendi. I do not think about concluding an agreement." 72

On learning about the negotiations, at the beginning of March 1948 Pope Pius XII received on an audience László Velics, Hungarian Ambassador to Rome - that was the first occasion since the Ambassador's arrival to Rome. At the audience Pius XII asked the diplomat whether his mandate to conduct negotiations on the relations between the Holy See and Hungary was still valid. After the ambassador's affirmative answer he said in strict confidence that "he would be willing to start diplomatic intercourse"73 and explained the viewpoint of the Holy See: ensuring the pedagogic role of the Church, authorisation of the Catholic Church and Catholic associations. Velics proposed to send a Vatican personage to Hungary in order to obtain information. These views meant a turning point after the earlier reticence.

Having analysed the dialogue, one can draw two conclusions: 1) The Holy See regarded the political transformation of East-Central Europe as a status quo and did not expect rapid change. From earlier statements of the Vatican it was clear that the Holy See was willing to conclude Concordats with mature, functioning states, irrespective of their political hue, in order to promote the interests of the Catholic Church. 2) With the negotiations the Holy See wanted to help Hungarian Catholicism but it not calculate upon the conclusion of a Concordat. There are pros and cons of both conclusions. Whatever the reality was, there

69 MNL-OL, XIX-J-1-j, Vatikán-IV-14-487/pol. res./1947 (Box No. 1), “Magyarország és a Vatikán közötti kapcsolatok" The Report of the Hungarian Ambassador to Rome, László Velics to Foreign Minister Erik Molnár. Rome, 7 November 1947.

$70 \mathrm{lbidem}$.

71 AMAE, Série: Europe, 1944-1960, sous-série: Hongrie, dossier: 18. Questions religieuses, 1944-1949. 20r-v. The report of Henry Gauquié, French Ambassador to Hungary, addressed to the Foreign Minister, No. 40/EU, 24 January 1948.

72 Magyar Piarista Rendtartomány Központi Levéltára (Central Archives of the Hungarian Province of the Piarist Order), the bequest of István Albert, item No. 4, File "Egyház és állam - tárgyalások", Pro memoria about the discussion of 7 February 1948.

$73 \mathrm{MNL}-\mathrm{OL}, \mathrm{XIX-I-1-v,} \mathrm{3-c} \mathrm{item/4.} \mathrm{(Box} \mathrm{No.} \mathrm{38)} \mathrm{More} \mathrm{recent} \mathrm{happenings} \mathrm{of} \mathrm{the} \mathrm{relationship} \mathrm{between} \mathrm{Hungary} \mathrm{and}$ the Holy See. Report of Zoltán Halász. Rome, 7 March 1948. 
is no news about the resumption of the audience; when the nationalization of schools was admittedly put on the agenda, contact was suspended again. Nevertheless, the viable and satisfactory settlement of Church-state relations could have been achieved only by a direct agreement between the Hungarian state and Rome.

It was a serious mistake for the Hungarian Communist politicians to assume that the Apostolic See would conclude an agreement with the Hungarian Republic, without considering the real situation of Hungarian Catholics and the actions to be taken in this regard. During 1948 there was no progress in this field, on the contrary, the state-Church relationship aggravated at a rapid pace. The uncompromising attitude of Cardinal Primate Mindszenty played a key role in this process: he refused any compromise on behalf of the relentless fight against Communism and Bolshevism. Nevertheless, the Bench of Bishops was not homogenous; similarly to the rest of society there was a fault line: some of them thought that there was a need for a 'modus vivendi', because they took into account the long-lasting settlement of the Soviets in Central-Europe. They wanted to establish a role for Catholicism in the new historical situation by means of clever negotiations. However, by the end of 1948 there was no chance for an agreement.

The government put the blame on Cardinal Mindszenty for these disappointments, and with some justification. After the leaders of the Hungarian opposition had fled from the country, Mindszenty remained the only one who had the courage of his convictions and protested. In the autumn of 1948 it became more and more obvious that the power would swoop on the Cardinal. It must be admitted that Mindszenty had some vulnerable spots. He was criticised, because he did not recognize the Republic. Although he did not make any statement, which would justify this criticism, his actions - or rather the lack of certain actions - show that the criticism was not baseless. He refused to visit the President of the Republic, returned the President's letters unopened, he was not willing to communicate with the authorities of the new regime and he refused to draw a salary from the state. "We respect his courage, his resolute character and the dignity of his behaviour but you have to admit that some priests and the best informed Catholic elements of the country disapprove of his intransigency, narrow-mindedness, authoritarian and tactless frame of mind, his ability to provoke incidents and last but not least, his reactionary mentality in the strict meaning of the word. The arrogance, the refusal of accepting a fait accompli; the "no, no, never", which is honourable to some extent but too risky. The feudal Hungarian of the Horthy-era is embodied in this Prelate, who does not even have aristocratic ancestors. (...) It seems that he shares the vision of those, who think that there has not been a legitimate Hungarian government since the fall of Horthy, and the recent system is based on the bayonets of the occupying forces. ${ }^{174}$ - as the Cardinal was characterized by the French Ambassador to Budapest.

During the search of the Archiepiscopal Palace on 23 December 1948, many documents were found hidden in a metal casing, for example a summary of the meeting of the Executive Committee of Budapest of the Hungarian Workers' Party, held on 3 November 1948. (Apparently, the information flowed not only towards the state security.) So the Cardinal

74 AMAE, Série: Europe, 1944-1960, sous-série: Hongrie, dossier: 18. Questions religieuses, 1944-1949. 20v. The report of Henry Gauquié, French Ambassador to Hungary, addressed to the Foreign Minister, No. 40/EU, 24 January 1948. 
must have realised that the hour has come and the crusade against the priesthood and obviously against him was imminent. General Secretary Mátyás Rákosi personally attended the party forum and delivered a lecture. He declared that the democracy had replaced its earlier defensive policy with a full-scale offensive against the Catholic Church. "The weapons needed in the fight will be the same as the weapons used against the Communists in the years of illegality. And these will be used without mercy. No matter where and how the clerical reaction tries to survive, it has to face the iron-bound power of democracy. No more warnings will be given to the Church. The priests who speak about politics on the pulpit will be put in an internment camp or prison immediately... Up to now the state wanted to bring a Nuncio to Budapest; now the Vatican would want to send him but the democracy does not need the delegate of the Vatican anymore. " 75 At that time an Atlanticist idea prevailed in the Vatican, which opposed any compromise with the Soviet bloc. Some members of the Bench of Bishops as well as the Prince Primate, who was convicted and waited for the judgment of the Court of Second Instance, tried to resume the negotiations but all these attempts failed. The legal liaison with the Vatican was cut between 1949 and 1962. The communication with foreign-based institutes was permitted only through the State Office for Church Affairs, which was established in 1950 in order to mediate and execute Church policy and supervise the Churches. The conditions of a rapprochement were created at the beginning of the 1960s. On the one hand, the Kádár-government showed more tolerance towards the Hungarian Catholic Church, which was on the edge of viability; on the other, the "aggiornamento" of the Universal Church and the commitment of the Vatican to efforts for world peace opened the door to the resumption of the negotiations in 1963. Even in the years following the Helsinki Declaration the establishment of diplomatic relations was impossible, because it was vetoed by the Soviets which had binding force in every country of the Soviet bloc. The initiatives to resume or retain the diplomatic relations failed in the other Eastern or Central-European countries, too. The Vatican's scepticism and its lack of motivation to continue the negotiations might have contributed to it; but the main cause behind this failure lay in Stalin's decision to sovietize East-Central Europe.

\section{Abstract}

Diplomatic relations are established by the Holy See and not by the Vatican, therefore it is accurate to speak about the diplomatic relations of the Holy See and not that of the Vatican. This analysis would like to outline how the representatives of the Holy See, assigned to the East-Central European countries, could work in the new political situation after World War II. It tries to set it in the context of the new social, political and geographical field, which this region entered as an area occupied by the Red Army.

In the interwar period the Holy See concluded concordats with some countries of the East-Central European region (with Poland, Romania, the German Reich, Austria and the Kingdom of the Serbs, Croats and Slovenes; it signed a 'modus vivendi' with Czechoslovakia and concluded the Lateran Treaty with Italy). In the case of Hungary, a so-called 'intesa semplice' entered into force in 1927 that was not a bilateral, international treaty, this is why

75 ÁBTL, 3.1.9. V-700/11, fol. 324/8-9, Confidential memo, found in the material of the house search at Mindszenthy [!]. 
it is called "simple agreement".

Yet in general it is true that between 1944/45 and 1947/48 it was in the interests of nearly every East-Central European government to show religious tolerance to some extent and maintain connections with the Holy See. Marxism was not an insurmountable obstacle for the Holy See, since it had diplomatic relations with Muslim countries as well. Rome distinguishes between governments and ideologies; namely, it represents an intransigent position as regards ethical or religious principles, at the same time it does not refuse to enter into negotiations with any political figure or group. However, in the long run the Papal Nunciatures were not allowed to remain in the countries of the Soviet sphere of influence, whether or not the given country was on the winning or losing side of the war.

\section{Keywords}

Holy See, Catholic Church, Soviet Union, Russian Orthodox Church, Concordat, diplomatic relations, Nunciature, Apostolic Nuncio, Hungary, Czechoslovakia, Yugoslavia, Poland, Romania, Albania, Bulgaria, Prince Primate József Mindszenty, Hungarian Catholic Church

\section{References}

Állambiztonsági Szolgálatok Történeti Levéltára (ÁBTL)

Historical Archives of the Hungarian State Security

\section{f. 3.1.9. V-700}

Archives du Ministères des Affaires étrangères (AMAE)

Archive of the Ministry of Foreign Affairs

Série: Europe, 1944-1960, sous-série: Hongrie

Arhiv Vniesniey Politiki Rossiyskoy Federacii (AVP RF)

The Interior Politics Archive of Russian Fedeation

f. 06., f. $56 b$

Gosudarstvennyj Arhiv Rossiskoj Federacii (GARF)

The Russian Federation State Archive

$$
\text { f. 6410, f. } 6991
$$

Magyar Nemzeti Levéltár Országos Levéltára (MNL-OL)

The State Archives of The National Archives of Hungary

f. XIX-J-1-j-Szovjetunió-IV-270, XIX-J-1-j, XIX-J-1-u, XIX-I-1-v

Magyar Piarista Rendtartomány Központi Levéltára

Central Archives of the Hungarian Province of the Piarist Order

The bequest of István Albert

Prímási Levéltár, Esztergom (EPL)

Esztergom Primatial Archives

Processus Joseph Card. Mindszenty: V-700/27, V-700/30, V-700/32

Politikatörténeti és Szakszervezeti Levéltár (PSL)

The Archives of Political History and Trade Unions 
Országos Széchényi Könyvtár Kézirattára (OSzKK)

National Széchényi Library, Manuscript Collection (OSzKK)

f. 216

L'Osservatore Romano, 1948, Year 88, No. 154.

A katolikus egyház Csehszlovákiában, in: L'Osservatore Romano, 88, 1948, 154, 5-6.

BALOGH, Margit: A szentszéki-magyar kapcsolatok a koalíció (1945-1949) éveiben, in: Magyarország és a római Szentszék. Magyarország és a római Szentszék. (Források és távlatok.) Tanulmányok Erdő bíboros tiszteletére, Budapest-Róma 2012 (Bibliotheca historiae ecclesiasticae Universitatis Catholicae de Petro Pázmány nuncupatae. Series 1. Collectanea Vaticana Hungariae. Classis 1/8.), 367-426.

BEKE, Margit (ed.): A magyar katolikus püspökkari tanácskozások története és jegyzőkönyvei 1945-1948 között, Köln-Budapest 1996.

CSIZMADIA, Andor: A magyar állam és az egyházak jogi kapcsolatainak alakulása és gyakorlata a Horthy-korszakban, Budapest 1966.

ERDŐ, Péter: A Szentszék és Magyarország, in: Katolikus Szemle, 43, 1991, 3-4, 140-148. FEIGE, Gerhard: Bulgarien, in: Kirche und Katholizismus seit 1945, II. Ostmittel-, Ost- und Südosteuropa, GATZ, Erwin (ed.), Paderborn-München-Wien-Zürich 1999, 56-61.

GERGELY, Jenő: A 20. században (1918-1995), in: Magyarország és a Szentszék kapcsolatának ezer éve, ZOMBORI, István (ed.), Budapest 1996, 255-292.

GERGELY, Jenő: A magyarországi katolikus egyház és a külpolitika (1948-1990), in: Magyar külpolitikai gondolkodás a 20. században, PRITZ, Pál (ed.), Budapest 2006, 39-59.

CHENAUX, Philipe: L'Église catholique et communisme en Europe (1917-1989). De Lénine à Jean-Paul II, Paris 2009.

ISPÁNKI, Béla: Az évszázad pere, Abaliget 1995.

KAPLAN, Karel: Stát a církev v Československu. 1948-1953, Brno 1994.

KŁOCZOWSKI, Jerzy - MÜLLEROWA, Lidia - SKARBEK, Jan: A katolikus egyház Lengyelországban, Budapest 1994 (Ecclesia Sancta 8.).

Konkordat zawarty pomiędzy Stolicą Apostolską a Rzecząpospolitą Polską podpisany w Rzymie dnia 10 lutego 1925 r., Lwów 1925.

Konkordátum a Szentszék és a Német Birodalom között (1933. július 20.), in: NÉMETH, István, Demokrácia és diktatúra Németországban, 1918-1945 2. kötet. A "Harmadik Birodalom", 1933-1945. Összegzés és dokumentumok, Budapest 2007.

KOPIEC, Jan: Polen, in: Kirche und Katholizismus seit 1945. Band 2. Ostmittel-, Ost- und Südosteuropa, GATZ, Erwin (ed.), Paderborn-München-Wien-Zürich 1999, 95-131.

LOMBARDI, Lapo: La Santa Sede e i cattolici dell'Europa Orientale agli albori della guerra fredda, Róma-Budapest 1997.

LŐRINCZ, Zsuzsa B. (ed.): A vatikáni magyar követ jelenti..., Budapest 1969.

MINDSZENTY, József: Emlékirataim, Budapest 1989.

Modus vivendi. Úmluva mezi republikou Československou a Svatou stolicí zjednána v lednu 1928 [online]. http://spcp.prf.cuni.cz/dokument/modus.htm (Visited: 18 February 2012). MRKONJIĆ, Tomislav: Archivio della Nunziatura Apostolica in Ungheria (1920-1939). Gli archivi della Santa Sede e il Regno d'Ungheria (secc. 15-20). A cura di Gaetano Platania - Matteo Sanfilippo - Péter Tusor, Budapest-Roma 2008. (Bibliotheca Historiae Ecclesiasticae Uiversitatis Catholicae de Petro Pázmány Nuncupatae. Ser. 1., Collectanea Vaticana Hungariae. Classis 1.). 
POLZOVICS, Iván: A lateráni szerződés. A szentszék nemzetközi jogi helyzete, Budapest 1934 (Szt. István könyvek 114.) [online]. http://www.ppek.hu/konyvek/Polzovics_Ivan_A_ laterani_szerzodes_1.pdf (Visited: 28 May 2014).

RÓNAY, Miklós: A Szentszék és a Vatikán Városállam viszonya a közbeszédben és a jogban, Külügyi Szemle Vol. 3, 2004, 271-298.

RÓNAY, Miklós: Az egységesség elve a katolikus egyház külügyi tevékenységében. PhD dissertation, Corvinus University, Budapest 2006.

SKAROVSKI, Mikhail, V.: Russkaia Pravoslavnija Cerkov pri Staline i Khrushceve (gosudarstvennoje-cerkovnie otnoseniya v SSSR v 1939-1964 godah), Moscow 2005.

STEHLE, Hansjakob: Geheimdiplomatie im Vatikan. Die Päpste und die Kommunisten, Zürich 1993.

SZUROMI, Szabolcs Anzelm: Egyházi intézménytörténet, Budapest 2003.

TÖRÖK József (ed.): Grősz József kalocsai érsek naplója 1944-1946. S. a. r., Budapest, n. d. [1995], 192.

TUSOR, Péter (ed.): Magyarország és a római Szentszék. (Források és távlatok.) Tanulmányok Erdő bíboros tiszteletére, Budapest-Róma 2012 (Bibliotheca historiae ecclesiasticae Universitatis Catholicae de Petro Pázmány nuncupatae. Series 1., Collectanea Vaticana Hungariae. Classis 1/8.).

VASILE, Cristian: The Apostolic Nunciature in Romania at the beginning of the communist regime, in: Instituto Romeno Di Cultura e Ricerca Umanistica (Venezia) Annuario Vol. 4, MARIN, Şerban - BULEI, Ion - DINU, Rudolf (eds.), Bucarest 2002, 255-261.

VECSEY, József (ed.): Mindszenty okmánytár. Pásztorlevelek, beszédek, nyilatkozatok. Vol. 1. Mindszenty tanítása, Munich 1957.

VOLK, Ludwig: Das Reichskonkordat vom 20. Juli 1933. Von den Ansätzen in der Weimarer Republik bis zur Ratifizierung am 10. September 1933, Mainz 1972. (Veröffentlichungen der Kommission für Zeitgeschichte, Reihe B: Forschungen, Bd. 5).

VOLOKITINA, Tatiana - MURAŠKO, Galina - NOSKOVA, Albina: Moskva i Vostochnaya Evropa. Vlasty i cerkov $v$ period obsestvennih transformacii 40-50-h godov XX veka, Moscow 2008.

ZOMBORI, István (ed.): Le relazioni diplomatiche tra I'Ungheria e la Santa Sede 1920-2000, Budapest 2001.

ZOMBORI, István (ed.): Magyarország és a Szentszék kapcsolatának ezer éve, Budapest 1996.

http://www.catholic-hierarchy.org/bishop/bmazzoli.html (Visited: 28 May 2014). 